\title{
Language Learning Motivation among Senior High School Students
}

\author{
Gartika Pandu Bhuana \\ STKIP Siliwangi Bandung
}

\begin{abstract}
Motivation is one of main determinant factor in learning second or foreign language. There are two types of motivation, which are integrative and instrumental motivation. Both of them play an essential role of the success in learning second or foreign language. Unfortunately, there is some debate about which kind of motivation is important for second language learner. Therefore, the aim of this study is to investigate the senior high school students' motivation toward learning English as a second language. The study is quantitative design. The participant of this study was twelve grade students at one of senior high school in Bandung. The data were obtained through questionnaire. The used questionnaire was integrative and instrumental motivation scale of Gardner's Attitude/Motivation Test Battery (AMTB) that is adapted by Vaezi (2010). The questionnaire has 5-point scale ranged from "strongly disagree" to "strongly agree". The data gained then was analyzed using SPSS 16.0. The result of the study showed that senior high school students were instrumentally motivated in learning English as a second language. In their point of view, learning English was important for supporting their future job and career.
\end{abstract}

Keywords: Integrative and instrumental motivation, senior high school students

\section{Introduction}

Mcmilan's dictionary (1979) defines motivation as providing with a motive, moving to effort, or action. Gardner (1985 in Qashoa, 2006) states that motivation involves four aspects: a goal; an effort; a desire to attain the goal; and a favorable attitude toward the activity. In line with this, Oxford and Erman (in Setiawati, 2011) defines motivation as significant goal or need; desire to attain the goal; and value of potential outcome or reward. To conclude, motivation deals with a desire and effort to gain a goal.

Motivation is one of the key factors in second language learning (Dornyei in Qahoa, 2006). It determines the second language achievement and attainment (Lucas, 2010). Motivation is classified into two types: integrative and instrumental motivation. The first one refers to the reasons that prompt the individual to learn about, interact with or become closer to the second language community (Gardner, 1985 cited in Waugh, 2004). This is in line with Dornyei (2003 in Waugh, 2004) who states that

"Integrative motivational orientation concerns a positive interpersonal/affective disposition toward the L2 group and the desire to interact with and even become similar to valued members of that community. It implies an openness to, and a respect for, other cultural groups and ways of life" (2003, p. 5). 
From the above definition, it can be inferred that integrative motivation deals with the intention to become a part of the target language community. In other words, the learners who have integrative motivation want to learn the language because they want to know the people who speak the language as well as they are interested in culture associated with that language.

The last one is instrumental motivation. Gardner (2001 in Waugh, 2004) states that person who acquire languages through instrumental motivation are seeking a goal that does not seem to involve any identification or feeling of closeness with the other language group, but instead focus on a more practical purpose [that] learning the language would serve for the individual. He also asserts that people who are instrumentally motivated tend to have a desire to gain social recognition or economic advantages through knowledge of a foreign language (cited in Waugh, 2004). In sort, instrumental motivation refers to motivation based on a more practical need to communicate in the second language. In other word, it deals with potential utilitarian gains of second language (L2) proficiency, such as getting a better job, higher salary, or salary bonus.

Despite the fact that both motivation types are essential for the success in learning second language, much debate among educators have been taking place about which kind of motivation is more important for L2 learners. Gass and Selinker (2010 in Vaezi, 2009) states that for a long time, integrative motivation was regarded as superior to instrumental motivation for predicting the success of second language learning. They added that if the students respected the target culture, they read a literature or practice the language, and thereby be able to improve their language skill. In contrast, Oxford (1996 in Vaezi, 2009) states that instrumental motivation is meaningful for learner who has limited access to the second language culture or foreign setting. This is supported by Vaezi (2009) who utters that generally students select instrumental reason frequently rather than integrative reason for the study of second language.

The above debate finally leads this study to investigate which of the types of motivation becomes the primary source of students in learning English as the second language. Particularly, this study aims to discover senior high school students' motivation toward learning English.

\section{Research Methodology}

This study applied quantitative method. It is used since its ability to investigate social or human problem with statistical procedure. As Creswell (1994) states that quantitative study is an inquiry into social or human problems, based in testing theory composed a variable, measured with number and analyzed with statistical procedure in order to determine whether the predictive generalization of the theory hold true.

The participant of this study was twelve grade students at one of senior high school in Bandung. There were 25 students which consist of 11 males and 14 females. Regarding the data collection techniques, this study used students' questionnaire. The questionnaire used here was the integrative and instrumental motivation scale of Gardner's Attitude/Motivation Test Battery (AMTB) that is adapted from Vaezi (2009). The questionnaire used 5-point scale that was ranged from "strongly disagree" to "strongly agree". It was divided into two part. The first part cosisted of 12 items (item 1-12, see Appendix) that showed the students' integrative motivation toward the target language. Meanwhile, second part includes 13 items (item 13-25, 
see Appendix) in which the participants were asked to measure their utilitarian reason for learning English.

For the data analysis, the data gained through questionnaire was analyzed by using SPSS 16. Descriptive statistic (frequency, mean, and standard deviation) was found out for all items involved in this study. The paired sample T-test then was used to find out the difference between students' integrative and instrumental motivation.

\section{Result}

1. Integrative and Instrumentally

As previously stated, integrative motivation focuses on the intention to know the target language community as well as interest to learn the culture. The following table shows the comparison between the mean score of the questions in integrative part.

Table 1.

Descriptive Statistics of the 12 Items on integrative motivation $(n=25)$

\begin{tabular}{|l|c|c|c|c|c|c|c|}
\hline Items: I study English ... & $\mathbf{1}$ & $\mathbf{2}$ & $\mathbf{3}$ & $\mathbf{4}$ & $\mathbf{5}$ & $\mathbf{M}$ & SD \\
\hline $\begin{array}{l}\text { Q1: to be more at ease with } \\
\text { other people who speak } \\
\text { English }\end{array}$ & - & 3 & 2 & 5 & 15 & 4.28 & 1.061 \\
\hline $\begin{array}{l}\text { Q2: to meet and converse } \\
\text { with more and varied } \\
\text { people }\end{array}$ & - & & 4 & 8 & 13 & 4.36 & .757 \\
\hline $\begin{array}{l}\text { Q3: to better understand } \\
\text { and appreciate English art } \\
\text { and literature }\end{array}$ & - & 6 & 8 & 5 & 6 & 3.64 & 1.150 \\
\hline $\begin{array}{l}\text { Q4: to participate more } \\
\text { freely in the activities of } \\
\text { other cultural groups }\end{array}$ & 3 & 4 & 8 & 6 & 4 & 3.16 & 1.248 \\
\hline $\begin{array}{l}\text { Q5: to know the life of the } \\
\text { English-speaking nations }\end{array}$ & 2 & 7 & 11 & 3 & 2 & 2.84 & 1.028 \\
\hline $\begin{array}{l}\text { Q6: to understand English } \\
\text { pop music }\end{array}$ & - & - & 5 & 14 & 6 & 4.04 & .676 \\
\hline $\begin{array}{l}\text { Q7: } \text { The more I get to } \\
\text { know native English } \\
\text { speakers, the more I like } \\
\text { them }\end{array}$ & 3 & 1 & 18 & 1 & 2 & 2.92 & .954 \\
\hline $\begin{array}{l}\text { Q8: to know various } \\
\text { cultures and peoples }\end{array}$ & 1 & 5 & 14 & 2 & 3 & 4.00 & .707 \\
\hline $\begin{array}{l}\text { Q9: to keep in touch with } \\
\text { foreign friends and } \\
\text { acquaintances. }\end{array}$ & - & 1 & 3 & 13 & 8 & 4.12 & .781 \\
\hline $\begin{array}{l}\text { Q10: to know more about } \\
\text { native English speakers }\end{array}$ & - & 3 & 4 & 11 & 7 & 3.88 & .971 \\
\hline Items: I study English .... & $\mathbf{1}$ & $\mathbf{2}$ & $\mathbf{3}$ & $\mathbf{4}$ & $\mathbf{5}$ & $\mathbf{M}$ & SD \\
\hline
\end{tabular}




\begin{tabular}{|l|l|l|l|l|l|l|c|}
\hline $\begin{array}{l}\text { Q11: The British are kind } \\
\text { and friendly }\end{array}$ & - & 2 & 17 & 5 & 1 & 3.20 & .645 \\
\hline $\begin{array}{l}\text { Q12: The Americans are } \\
\text { kind and cheerful }\end{array}$ & 1 & 4 & 13 & 2 & 5 & 3.24 & 1.091 \\
\hline Overall mean score & \\
\hline $\begin{array}{l}\text { Note: Mean classification } 2.5-3.25=\text { Low ; 3.25 - } \\
\text { 4.00 - 5.00 = high }\end{array}$ \\
\hline
\end{tabular}

From the above table, it can be seen that the mean of question number 1, 2, 6, 8, and 9 are above 4.00. This indicates students' high motivation to meet, talk, and keep in touch with English native speaker. They are also highly motivated to know the English culture, especially the music. Meanwhile, the mean of question number 3 and 10 are below 3.25, which implies students' moderate motivation. At this point, the students have little interest to know about the English art/literature and to know more about English native speaker. In other words, they do not want to know English native speaker life or privacy. Regarding the mean of question numbers $4,5,7,11$, and 12 , they stay under 3.25. This is considered as low. The students, in this case, are low motivated to participate in cultural activity of the target language. They also do not have high interest to know about the life of English people. This supports the statement in number 10 .

Meanwhile, instrumental motivation refers to motivation based on a more practical need to communicate in the second language. In other word, the learners want to learn the second language to gain something from it. The table below presents the mean score of the students' instrumental motivation.

Table 1.

Descriptive Statistics of the 13 Items on the instrumental motivation $(n=25)$

\begin{tabular}{|l|c|c|c|c|c|c|c|}
\hline I study English because.... & $\mathbf{1}$ & $\mathbf{2}$ & $\mathbf{3}$ & $\mathbf{4}$ & $\mathbf{5}$ & $\mathbf{M}$ & $\mathbf{S D}$ \\
\hline $\begin{array}{l}\text { Q13: I'll need it for my future } \\
\text { career. }\end{array}$ & - & - & - & 2 & 23 & 4.92 & .277 \\
\hline $\begin{array}{l}\text { Q14: it will make me a more } \\
\text { knowledgeable person. }\end{array}$ & - & 2 & 12 & 6 & 5 & 3.64 & .952 \\
\hline $\begin{array}{l}\text { Q15: it will someday be useful } \\
\text { in getting a good job. }\end{array}$ & - & - & - & 1 & 24 & 4.96 & .200 \\
\hline $\begin{array}{l}\text { Q16: other people will respect } \\
\text { me more if I know English. }\end{array}$ & 4 & 3 & 14 & 3 & 1 & 2.76 & 1.012 \\
\hline $\begin{array}{l}\text { Q17: I will be able to search for } \\
\text { information and materials in } \\
\text { English on the Internet. }\end{array}$ & - & - & - & 8 & 17 & 4.64 & .490 \\
\hline $\begin{array}{l}\text { Q18: I will learn more about } \\
\text { what's happening in the world. }\end{array}$ & - & 1 & 4 & 7 & 13 & 4.24 & 1.012 \\
\hline $\begin{array}{l}\text { Q19: language learning often } \\
\text { gives me a feeling of success. }\end{array}$ & 6 & 3 & 9 & 4 & 3 & 2.84 & 1.375 \\
\hline $\begin{array}{l}\text { Q20: language learning often } \\
\text { makes me happy. }\end{array}$ & 2 & 1 & 12 & 7 & 3 & 3.32 & 1.030 \\
\hline I study English because... & $\mathbf{1}$ & $\mathbf{2}$ & $\mathbf{3}$ & $\mathbf{4}$ & $\mathbf{5}$ & $\mathbf{M}$ & SD \\
\hline
\end{tabular}




\begin{tabular}{|l|l|l|l|l|l|l|l|}
\hline $\begin{array}{l}\text { Q21: an educated person is } \\
\text { supposed to be able to speak } \\
\text { English. }\end{array}$ & 3 & 2 & 7 & 9 & 4 & 3.36 & 1.221 \\
\hline $\begin{array}{l}\text { Q22: I can understand English- } \\
\text { speaking films, videos, TV or } \\
\text { radio. }\end{array}$ & - & 2 & 4 & 8 & 11 & 4.08 & 1.038 \\
\hline Q23: I can read English books. & 2 & 3 & 9 & 7 & 4 & 3.32 & 1.145 \\
\hline $\begin{array}{l}\text { Q24: to know new people from } \\
\text { different parts of the world. }\end{array}$ & 1 & 3 & 14 & 5 & 2 & 3.16 & .898 \\
\hline $\begin{array}{l}\text { Q25: without it one cannot be } \\
\text { successful in any field. }\end{array}$ & - & - & 3 & 8 & 14 & 4.44 & .712 \\
\hline \multicolumn{7}{|c|}{ Overall mean score } \\
\hline \begin{tabular}{l} 
Note: Mean classification 1 - 2.75 = Low ; 2.75-3.75= moderate $; 3.75$ \\
\hline
\end{tabular} \\
\hline
\end{tabular}

In instrumental part, the students were highly motivated in the question number 13 . In this case, they are realized that as second language, English plays an important part to get their future job. In addition, the question number 13, 17, 18, 22, and 25 also shows students' high motivation. The other questions, exactly 14, 16, 19, 20, 21, 23, and 24 illustrated students' moderate motivation. Similar with the integrative, overall mean score in this part signified students moderate motivation toward learning English. At this point, they are not really enthusiasm to gain something trough learning English.

By comparing the means score of integrative (3.64) and instrumental motivation (3.82), it can be seen that the students in certain extent are instrumentally motivated. However, to know the significance different between those two motivations T-Test are used. The result can be seen in the following session.

The aim of paired sample t-test is to make sure that there is a significance differences between the students' integrative and instrumental motivation. The result is illustrated in the following table:

Paired Samples Test

\begin{tabular}{|c|c|c|c|c|c|c|c|c|}
\hline & \multicolumn{5}{|c|}{ Paired Differences } & \multirow[b]{3}{*}{$\mathrm{t}$} & \multirow[b]{3}{*}{ df } & \multirow{3}{*}{$\begin{array}{l}\text { Sig. (2- } \\
\text { tailed) }\end{array}$} \\
\hline & \multirow{2}{*}{$\begin{array}{c}\text { Mea } \\
\mathrm{n}\end{array}$} & \multirow{2}{*}{$\begin{array}{c}\text { Std. } \\
\text { Deviati } \\
\text { on }\end{array}$} & \multirow{2}{*}{$\begin{array}{l}\text { Std. } \\
\text { Error } \\
\text { Mean }\end{array}$} & \multicolumn{2}{|c|}{$\begin{array}{c}95 \% \\
\text { Confidence } \\
\text { Interval of } \\
\text { the } \\
\text { Difference } \\
\end{array}$} & & & \\
\hline & & & & Lower & Upper & & & \\
\hline $\begin{array}{ll}\text { Pair } & \mathrm{x} 1- \\
1 & \mathrm{x} 2\end{array}$ & $\begin{array}{r}6.00 \\
0\end{array}$ & 5.759 & 1.152 & -8.377 & -3.623 & $\begin{array}{r}5.20 \\
9 \\
\end{array}$ & 24 & .000 \\
\hline
\end{tabular}

From the t-test result, it is found that the mean between integrative and instrumental motivation is -6 with 24 of standards deviation. Moreover, it is also discovered that 
significance $(0.000)$ is less than 0.05 . It means that there is a significance differences between the students' integrative and instrumental motivation.

This study is conducted to determine which of the two types of motivation - integrative and instrumental - can be the primary source for senior high school students' motivation toward learning English as second language. The data of the finding shows that the students have greater emphasis on instrumental reason for learning English language than the integrative one. Even though the disparity is not quite bigger, the result of paired t-test illustrates that there is a significance differences between them. This indicates that students are motivated to learn English as the second language in order to gain something from it, which is in this case is related to their future career or job.

Regarding to the integrative motivation taking place on the second position after the instrumental one, this indicates that the students' interest in learning English as second language and its culture has the least impact on their motivation. It is probably because they have less opportunity to directly interact with the native speaker. This fact is such an irony. As it has been known, the access to have direct contact with the native speaker is widely opened. There is a social networking, chatting, and other media that can be used as mediator. Nevertheless, the students is more interested in watching English film and video as well as listening to its music rather than having direct contact with them. It implies that students only think English as the need for their future job or career. They are not really like them and want to know more about it.

The data findings indirectly against Gass and Selinker (2001 in Vaezi, 2009) statements that integrative motivation was regarded as superior to instrumental motivation for predicting the success of second language learning. However, instrumental motivation is also meaningful for learner in learning a second language. In this case, the students attempt to develop their language ability for the sake of their future career. They will be motivated to study the second language hard at this point. Therefore, this type of motivation can be considered as important motivation.

\section{Conclusion}

Basicaly, both integrative and instrumental motivation contributes to the second language learning. There is no motivation that is considered as the superior. As Ellis (1997 in Vaezi, 2009) states, both integrative and instrumental motivation are essential element of learning success. Unfortunately, the finding of this study shows that senior high school students are instrumentally motivated in learning English as a second language. In their point of view, learning English is important for supporting their future, especially for getting a job. In this case, the students are less interested to know about English culture or to interact with the native speaker. Finally, this study confirms the opinion of some researchers who believe that in a foreign language situation students are instrumentally oriented. 


\section{Reference}

Carreira, Junko. 2006. Motivation for Learning English as a Foreign Language in Japanese Elementary Schools. Retrieved on January 6, 2012 from jaltpublications.org/archive/jj/.../art2.p... - Jepang

Creswell, J. W. 1994. Research Design: Qualitative \& Quantitative Approaches. New Delhi : Sage Publications.

Lucas, Rochele. 2010. A Study in the Intrinsic Motivation Factors in Second Language Learning among Selected Freshman Students. Retrieved on January 6, 2012, from www.philippine-esl-journal.com/V4_Al.pdf

Qashoa, Sulaiman. 2006. Motivation among Learners of English in The Secondary School in the Eastern Coast of the UAE. Retrieved on January 6,2012 from www.asian-efljournal.com/thesis_Sulaiman_...

Setiawati, Liani.2011. Chapter Report on Individual Differences. Unpublish Paper at Indonesia University of Education.

Vaezi, Zahra. 2009. Language Learning Motivation among Iranian Undergraduate Students. Retrieved on January 6, 2012 from www.ijls.net/volumes/...vaezil.pdf

Waugh, Linda. 2004. Motivation and Its Role in Language Acquiaition. Retrieved on 6 January, 2012, from $w w w . u$. arizona.edu/.../... 
